\title{
Strategi Kesiapan Koperasi dalam Digitalisasi Perkebunan Kelapa Sawit Rakyat
}

\section{(Cooperatives' Readiness Strategy in Oil Palm Smallholders' Plantation Digitalization Program)}

\author{
A Faroby Falatehan ${ }^{1 *}$, Yusman Syaukat ${ }^{1}$, Hariyadi $^{2}$, Sriwulan Ferindian Falatehan ${ }^{3}$
}

(Diterima Mei 2021/Disetujui September 2021)

\begin{abstract}
KUD Tunas Muda merupakan salah satu koperasi yang aktif menggunakan teknologi informasi dalam melayani kebutuhan anggotanya, terutama terkait dengan kegiatan kelapa sawit. Namun, belum semua kegiatan persawitan oleh koperasi ini memanfaatkan digitalisasi. Tulisan ini bertujuan memberi gambaran kesiapan KUD yang berlokasi di Provinsi Riau ini dalam digitalisasi perkebunan kelapa sawit rakyat yang mencakup kegiatan dalam penyiapan input, budi daya, pemasaran, hingga penerimaan pembayaran. Selain itu, kajian ini juga bertujuan manganalisis prioritas strategi yang dapat dijalankan oleh koperasi dalam upaya digitalisasi sawit rakyat. Kajian ini menggunakan dua metode analisis, yaitu analisis deskriptif dan analytical hierarchy process. Berdasarkan hasil kajian, peran pengurus koperasi cukup besar dalam menginisiasi dan membangun sistem digital dalam layanan untuk anggotanya, hal ini karena KUD tersebut telah berpengalaman melaksanakan digitalisasi, walaupun fungsinya masih terbatas. Strategi yang diprioritaskan adalah dengan meningkatkan pemahaman petani sawit terutama anggota dalam menggunakan teknologi dan informasi digital guna mendukung kegiatan digitalisasi perkebunan sawit.
\end{abstract}

Kata kunci: analytical hierarchy process, budi daya, KUD Tunas Muda, perkebunan rakyat, teknologi informasi

\section{ABSTRACT}

KUD Tunas Muda is one of the cooperatives active in using information technology to serve the needs of its members, especially related to oil palm activities. However, not all palm oil activities have been carried out through digitization. This paper aims to provide an overview of the readiness of the KUD located in Riau Province in digitizing smallholder oil palm plantations, which include activities in preparing inputs, cultivation, marketing, and receiving payments. This study also aims to analyze strategic priorities that cooperatives can carry out in digitizing smallholder palm oil. This study uses two methods in its analysis, namely descriptive analysis, and analytical hierarchy process. Based on the study, cooperative management is quite prominent in initiating and building digital systems in services for their members. This is because the KUD already has experience in digitalization, although the function is still limited. According to the analysis, the prioritized strategy is to increase the understanding of oil palm farmers, especially among members, in using digital technology and information to support the digitalization of oil palm plantations.

Keywords: analytical hierarchy process, cultivation, information technology, KUD Tunas Muda, smallholder plantation

\section{PENDAHULUAN}

Digitalisasi tengah melanda seluruh dunia, tidak terkecuali di Indonesia. Digitalisasi telah banyak mengubah berbagai lini kehidupan, termasuk di sektor ekonomi. Penggunaan teknologi digital telah diakui sebagai salah satu tantangan besar bagi bisnis abad ke-21. Digitalisasi ini ditandai dengan penggunaan teknologi informasi (TI) secara intensif di berbagai tahapan rantai nilai. Dalam tautan ini, smart agriculture

\footnotetext{
${ }^{1}$ Departemen Ekonomi Sumberdaya dan Lingkungan, Fakultas Ekonomi dan Manajemen, Institut Pertanian Bogor, Bogor, 16680

2 Departemen Agronomi dan Hortikultura, Fakultas Pertanian, Institut Pertanian Bogor, Bogor, 16680

3 Departemen Sains Komunikasi dan Pengembangan Masyarakat, Fakultas Ekologi Manusia, Institut Pertanian Bogor, Bogor, 16680

* Penulis Korespondensi:

E-mail: alfaroby@apps.ipb.ac.id
}

mentransformasi sektor pertanian dari segi ekonomi, sosial, dan kelestarian lingkungan (Ciruela-Lorenzo et al. 2020).

Pada tahun 2030 Indonesia akan menerapkan konsep Revolusi Industri 4.0 secara besar-besaran melalui program "Making Indonesia 4.0." Revolusi ini akan berdampak pada koperasi sehingga Revolusi 4.0 ini juga akan menjadi tantangan bagi koperasi di era digital. Kunci agar koperasi mampu menghadapinya adalah dengan fokus pada pengembangan bisnis yang mengarah kepada anggota koperasi sehingga anggota koperasi dapat menjadi layanan prioritas yang harus dijaga kebutuhannya.

Kelapa sawit merupakan salah satu komoditas unggulan Indonesia. Manfaat komoditas ini bagi pemerintah, perusahaan kelapa sawit, dan masyarakat tidak sedikit (Sari et al. 2019). Industri kelapa sawit merupakan salah satu kontributor utama pembangunan ekonomi di Indonesia, selain dapat mengurangi kemiskinan karena industri ini telah mengubah ke- 
hidupan petani skala kecil secara positif (Falatehan \& Setiawan 2020). Koperasi Unit Desa (KUD) Tunas Muda merupakan salah satu KUD di Kabupaten Siak yang berkegiatan dalam perkelapasawitan. Pada awalnya koperasi ini didirikan untuk memfasilitasi para anggotanya yang merupakan petani plasma. Dengan koperasi ini, koordinasi kegiatan oleh para petani dalam kegiatan budi daya hingga pemasarannya menjadi lebih mudah.

Koperasi merupakan salah satu kebutuhan umum bagi petani untuk mengelola perkebunannya, terutama yang berkaitan dengan pengelolaan, tanaman, dan teknik keuangan (Afifah 2021). Menurut Putra et al. (2020), tingkat persepsi petani mengenai keberadaan koperasi dalam usaha perkebunan kelapa sawit rakyat adalah baik; petani sudah dapat menilai koperasi dengan dasar pengalamannya selama menggunakan jasa koperasi. Dalam meningkatkan peran koperasi, menurut Sujarwo \& Rodiana (2018), koperasi harus menggunakan TI dan komunikasi guna menunjang proses bisnis dan pelayanan anggota. Oleh karena itu, karakter kreatif dan inovatif bagi insan penggerak koperasi dapat dibangun melalui pendidikan dan pelatihan. Menurut Mosher (1991), pendidikan merupakan salah satu syarat pokok dalam pembangunan pertanian selain syarat pelancar. Beberapa syarat pelancar guna menunjang pembangunan pertanian walaupun tidak bersifat mutlak ialah (1) pendidikan pembangunan, (2) kredit produksi, (3) kegiatan bersama oleh petani, (4) perbaikan dan perluasan tanah pertanian, dan (5) perencanaan nasional pembangunan. Perkembangan teknologi dan digitalisasi berdampak banyak bagi perubahan gaya hidup masyarakat, termasuk aspek muamalah (hubungan manusia dalam berinteraksi). TI atau digitalisasi dapat juga digunakan untuk mempromosikan produk dan jasa, penggunaan fintech, dan platform digital transaksi daring. Hal inilah yang akan diterapkan pada KUD Tunas Muda. KUD ini berdiri sejak tahun 1990 dengan unit-unit seperti: (a) perkreditan; (b) unit simpan pinjam; (c) warung serba ada (waserda); (d) perekonomian lainnya seperti: bidang pertanian, peternakan, perkebunan, perikanan, dan kerajinan; (d) saprodi, pupuk, dan penyaluran BBM; dan (e) penyediaan/penggolahan/pemasaran hasil produksi.

Koperasi Tunas Muda merupakan salah satu koperasi yang telah mengadopsi TI dan digitalisasi dalam berkegiatan sehari-hari dengan anggotanya sehingga koperasi ini dipilih sebagai lembaga yang dapat dijadikan backbone bagi digitalisasi perkebunan sawit rakyat. Dengan digitalisasi dalam proses bisnis, maka transformasi digital pada organisasi dapat dicapai (Savic 2019). Meski telah menjalankan digitalisasi dalam kegiatan sehari-harinya, kegiatannya masih terbatas. Belum ada digitalisasi untuk hal yang terkait dengan produksi atau budi daya kelapa sawit. Sebenarnya, digitalisasi telah banyak digunakan pada beberapa perusahaan kelapa sawit di Indonesia, seperti di PT Astra Agro Lestari dan PT Smart. Pemanfaatan teknologi digital pada perkebunan sawit ini menyebabkan kegiatan menjadi semakin efektif dan kompetitif. Bahkan pada saat pandemik Covid-19, yang tidak memungkinkan perusahaan melakukan perjalanan, operasional pabrik dan kebun dapat dipantau langsung melalui operating center. Perangkat ini mampu menampilkan data harian kebun dan pabrik di seluruh wilayah operasi perusahaan. Data yang dihasilkan dari kegiatan digitalisasi ini dapat diteruskan secara akurat, lengkap, ringkas, dan tepat waktu sebagai dasar dalam pengambilan keputusan bisnis. Aplikasi berbasis digital ini tidak hanya untuk produksi, panen, angkut, dan logistik, tetapi juga digunakan untuk memantau aktivitas perawatan kebun yang selama ini masih menggunakan sistem konvensional dengan ratusan tenaga kerja.

Keunggulan digitalisasi ini dapat menjadi peluang bagi perkebunan rakyat untuk menggunakan digitalisasi sehingga dapat berkontribusi lebih besar. Pelaksanaan digitalisasi ini tidak mudah. Sani et al. (2017) meneliti kesiapan Pemerintah Kota Bogor dalam penerapan perencanaan pembangunan berbasis e-planning. Beberapa yang dipertimbangkan dalam kesiapan digitalisasi menurut peneliti tersebut adalah kualitas sumber daya manusia, khususnya para operator e-planning, dan beberapa faktor yang menunjukkan komitmen pada penerapannya.

KUD Tunas Muda telah menerapkan digitalisasi dalam usahanya tetapi masih terbatas cakupannya. KUD ini akan mengembangkan pemanfaatan digitalisasi ke arah yang lebih produktif lagi, yaitu digitalisasi dari segi penanaman, kebutuhan air, lahan, pupuk, pemasaran, hingga pembayaran hasil penjualan tandan buah segar kelapa sawit (TBS). Oleh karena itu, perlu dianalisis kesiapan KUD tersebut dalam digitalisasi perkebunan sawit rakyat. KUD ini pernah mendapat penghargaan tingkat nasional sebagai pemenang koperasi serba usaha dan koperasi produksi pada tahun 2005 dan 2008. Selanjutnya pada tahun 2018, diperoleh penghargaan sebagai KUD yang memiliki omzet terbesar tingkat Kabupaten Siak. Saat ini, aset yang dimiliki mencapai Rp14 miliar dengan jumlah anggota 423 orang.

Tulisan ini bertujuan memberi gambaran kesiapan KUD Tunas Muda dalam digitalisasi perkebunan kelapa sawit rakyat yang mencakup kegiatan penyiapan input, budi daya, pemasaran, hingga penerimaan pembayaran. Selain itu, kajian ini juga bertujuan manganalisis prioritas strategi yang dapat dijalankan oleh koperasi dalam melakukan digitalisasi sawit rakyat. Beberapa faktor yang digunakan dalam menganalisis kesiapan koperasi dalam digitalisasi perkebunan sawit rakyat merujuk pada penelitian oleh Sani et al. (2017), yaitu (1) tersedianya jaringan infrastruktur telekomunikasi, (2) tersedianya tenaga yang mengetahui pelaksanaan digitalisasi, dan (3) tersedianya lembaga pelaksana. 


\section{METODE PENELITIAN}

Penelitian dilaksanakan di Kabupaten Siak, pada KUD Tunas Muda di Kampung Teluk Merbau, Kecamatan Dayun, Kabupaten Siak, Provinsi Riau. Data primer diperoleh melalui wawancara langsung, observasi, serta diskusi dengan pengurus dan anggota KUD tersebut. Total responden adalah 20 orang. Data sekunder diperoleh melalui penelusuran karya-karya ilmiah, dokumen lembaga, laporan instansi dan lembaga terkait. Sementara itu, wawancara mendalam dengan beberapa responden, seperti pengurus KUD, akademisi, pemerintah, dan pihak perkebunan kelapa sawit swasta adalah untuk untuk menentukan prioritas strategi. Data sekunder diperoleh dari pihak-pihak yang terkait, yakni data dari BPS, Dinas Perkebunan Siak, Kantor Desa Teluk Merbau, KUD Tunas Muda, dan referensi lainnya. Data dikumpulkan sejak Agustus sampai Oktober 2020, meliputi data primer dan sekunder (Tabel 1).

Dalam penentuan prioritas strategi, digunakan analisis menggunakan program analytical hierarchy process (AHP). Model AHP menggunakan persepsi manusia yang dianggap pakar atau ahli sebagai input utamanya. Hal ini merupakan perbedaan mencolok antara model AHP dengan model pengambilan keputusan lainnya. Kriteria pakar atau ahli yang digunakan dalam analisis AHP lebih mengacu pada individu yang mengerti mengenai permasalahan yang diajukan, merasakan akibat suatu masalah, atau berkepentingan dengan masalah tersebut (Falatehan 2016). Dalam AHP, terdapat pembobotan yang nilainya antara 1 sampai 9 . Tabel 2 memuat nilai dan makna dari skala perbandingan Saaty.

Kerangka AHP pada penelitian ini didapat berdasarkan hasil analisis sebelumnya yang dianalisis (1) berdasarkan kondisi di lapangan serta berdasarkan dari penelitian sebelumnya (Sani et al. 2017).

Tabel 1 Keterkaitan antara tujuan dan metode analisis
Kerangka AHP terdiri atas 4 struktur, yaitu tujuan AHP; struktur kedua adalah faktor yang memengaruhi kesiapan digitalisasi perkebunan kelapa sawit rakyat. Dalam hal ini, beberapa faktor dan kendala yang digunakan diadopsi berdasarkan penelitian dari Sani et al. (2017), dan disesuaikan dengan kondisi di tempat kajian. Berikut ini adalah beberapa faktor yang memengaruhi penerapan digitalisasi, yaitu (1) tersedianya jaringan infrastruktur telekomunikasi, (2) tersedianya tenaga yang mengetahui pelaksanaan digitalisasi, dan (3) tersedianya lembaga pelaksana. Struktur ketiga adalah kendala dalam kesiapan digitalisasi, yaitu (1) jaringan infrastruktur telekomunikasi kurang baik, (2) pemahaman tentang penggunaan fasilitas $\mathrm{TI}$ pada perangkat telepon genggam terutama untuk usia lanjut dan, dan (3) masih banyaknya petani anggota yang menjual TBS ke tengkulak sehingga pemanfaatan kelembagaan kurang optimum.

Struktur keempat pada kerangka AHP di kajian ini adalah mengenai prioritas strategi, yaitu (1) bekerja sama dengan Pemerintah dan provider dalam meningkat-an cakupan sinyal, (2) peningkatan pemahaman anggota KUD Tunas Muda dalam menggunakan teknologi digital, (3) meningkatkan peran kelembagaan petani dalam KUD Tunas Muda untuk kemitraan tengkulak TBS dan pemasok input, dan (4) meningkatkan peran pemerintah dalam melindungi harga TBS. Struktur kerangka AHP didapat dari hasil diskusi dengan berbagai pemangku kepentingan yang mengerti masalah yang ada di lapangan sehingga struktur dan peubah yang ada sesuai dengan kondisi di lapangan. Analisis AHP menggunakan peranti lunak ExpertChoice.

\section{HASIL DAN PEMBAHASAN}

Layanan penjualan TBS KUD Tunas Muda kepada anggota koperasi sudah diterapkan melalui aplikasi,

\begin{tabular}{lllc}
\hline No & \multicolumn{1}{c}{ Tujuan } & \multicolumn{1}{c}{ Jenis Data } & Metode Analisis \\
\hline 1 & Menganalisis kesiapan digitalisasi KUD & Primer (diskusi dengan pengurus KUD dan petani) & Deskriptif \\
& $\begin{array}{l}\text { Tunas Muda dalam Digitalisasi } \\
\text { Perkebunan Rakyat. }\end{array}$ & $\begin{array}{l}\text { Sekunder (data yang terkait dengan kesiapan untuk } \\
\text { digitalisasi) }\end{array}$ & AHP \\
2 & $\begin{array}{l}\text { Menganalisis prioritas strategi yang } \\
\text { dapat dikerjakan oleh Koperasi Tunas }\end{array}$ & Primer & Hierarchy \\
& $\begin{array}{l}\text { Muda dalam digitalisasi perkebunan } \\
\text { sawit rakyat di Kabupaten Siak. }\end{array}$ & Process) \\
\hline
\end{tabular}

Tabel 2 Skala banding secara berpasangan dalam AHP

\begin{tabular}{cl}
\hline Intensitas & \\
\hline 1 & Kedua elemen sama pentingnya \\
3 & Elemen yang satu sedikit lebih penting daripada elemen yang lainnya \\
5 & Elemen yang satu lebih penting daripada elemen yang lain \\
7 & Elemen sang satu jelas lebih penting daripada elemen yang lain. \\
9 & Elemen yang satu mutlak lebih penting daripada elemen yang lain \\
$2,4,6,8$ & $\begin{array}{l}\text { - Nilai-nilai antara dua nilai pertimbangan yang berdekatan } \\
\text { - Jika untuk aktivitas ke- } i \text { mendapat satu angka bila dibandingkan aktivitas ke-j, maka } j \text { mempunyai nilai } \\
\end{array}$ \\
kebalikannya bila dibandingkan dengan $i$
\end{tabular}


tetapi data pelaporan hasil produksi, pemupukan, dan perawatan masih mengunakan pencatatan manual, terutama untuk petani swadya (bukan anggota tetap). KUD ini bekerja sama dengan Institut Pertanian Bogor, berupaya mengembangkan program digitalisasi yang didesain untuk mengumpulkan data digital terkait produksi (pengadaan pupuk, kondisi tanah dan air); perhitungan usaha tani di dalamnya; panen (panen, grading, pembayaran, dan pengangkutan). Oleh karena itu perlu dianalisis kesiapan KUD dan anggotanya dalam mengembangkan digitalisasi.

\section{Kesiapan Digitalisasi Perkebunan Kelapa Sawit Rakyat}

Pada bagian ini dibahas faktor-faktor kesiapan KUD Tunas Muda yang memengaruhi kesiapan digitalisasi perkebunan sawit rakyat, dengan menggunakan rujukan dari Sani et al. (2017). Berikut ini adalah beberapa faktor yang dimiliki oleh KUD dalam mengembangkan digitalisasi yang sudah ada.

- KUD Tunas Muda sebagai Lembaga Pelaksana Digitalisasi

KUD ini berdiri pada tahun 1990. Koperasi yang berada berada di Kabupaten Siak ini pada awalnya merupakan koperasi plasma perkebunan kelapa sawit yang anggotanya adalah para transmigran yang berasal dari Pulau Jawa, Pulau Madura, Pulau Bali, dan Provinsi Sumatra Utara. Anggota KUD sampai September 2020 berjumlah 423 orang; 100 orang di antaranya merupakan anggota tetap KUD tersebut dan termasuk petani plasma binaan PTPN V Kabupaten Siak, selebihnya sebanyak 323 orang merupakan anggota tidak tetap (anggota luar biasa). Pada bulan Februari 2020, status KUD menjadi Koperasi Syariah (Gambar 1).

Anggota tetap KUD merupakan petani plasma, yang ada sejak koperasi berdiri. Adapun anggota tidak tetap merupakan anggota yang dapat memanfaatkan fasilitas KUD, khususnya dalam penjualan TBS ke perusahaan kelapa sawit (PKS). Dalam UU No 25 Tahun 1992 tentang Perkoperasian, koperasi dapat memiliki anggota luar biasa yang persyaratan, hak, dan kewajiban keanggotaannya ditetapkan dalam

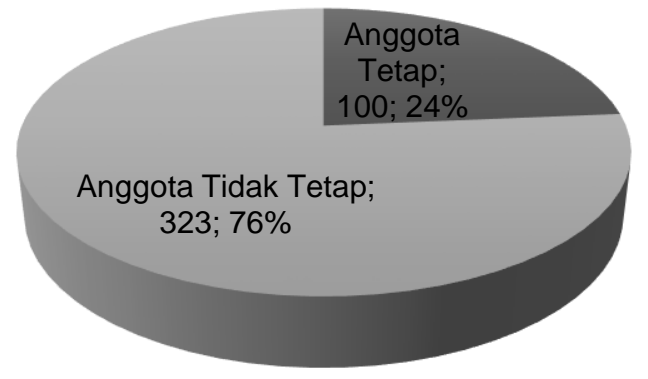

- Anggota Tetap $\quad$ Anggota Tidak Tetap

Gambar 1 Jumlah anggota tetap dan tidak tetap KUD Tunas Muda
Anggaran Dasar. Anggota luar biasa adalah mereka yang bermaksud menjadi anggota, tetapi tidak dapat memenuhi semua/seluruh syarat sebagai anggota. Selanjutnya pada UU Perkoperasian terbaru, yaitu UU No 17 Tahun 2012, jenis keanggotaan berdasarkan UU ini tidak menyebutkan anggota tidak tetap, yang ada adalah semua harus menjadi anggota atau tidak sama sekali. Hal ini sesuai dengan teori pengembangan institusi yang self-governing (Ostrom 1990), yakni melalui aturan operasional (rule in use) dan aturan kolektif (collective choice) mampu menjadi patokan tindak bagi setiap anggota masyarakat dalam memperlakukan sumber daya milik mangrove.

Penjualan TBS petani ke PKS tidak dapat langsung, tetapi harus melalui lembaga yang telah memiliki kontrak dengan PKS. KUD Tunas Muda merupakan KUD yang memiliki kontrak dari beberapa PKS, sehingga tidak sedikit yang menjual melalui KUD ini. Selain itu, KUD ini memiliki beberapa kegiatan dalam usaha perkebunan sawit, seperti mengelola penjualan TBS, simpan pinjam, serta penjualan pupuk. Sebagai koperasi plasma, koperasi ini memiliki kelebihan dalam penjualan TBS, yaitu telah memiliki kontrak dari beberapa perusahaan, seperti PTPN V, PT Sinar Agro Raya, dan PT Berlian Inti Mekar.

- Ketersediaan infrastruktur digital

Faktor-faktor yang menghambat penggunaan teknologi digital secara umum di tingkat petani, di antaranya adalah infrastruktur digital, seperti wifi untuk internet. Prasarana wifi menjadi yang paling utama mendukung digitalisasi. Kondisi wifi di KUD Tunas Muda cukup baik, tetapi infrastruktur ini dapat diakses anggota hanya pada saat berada di koperasi. Di luar lokasi KUD, anggota dapat menggunakan layanan digital dengan dukungan provider komunikasi yang tersedia di kampung Teluk Merbau, seperti Telkomsel, Indosat, dan XL. Infrastruktur pendukung digitalisasi, yaitu laptop atau komputer umum, sudah ada, dan telah dimanfaatkan oleh staf dan penggurus KUD.

Dalam kegiatan operasionalnya, KUD Tunas Muda telah menerapkan digitalisasi. Beberapa platform digital yang dipergunakan dalam aktivitas usaha perkebunan sawit rakyat adalah sebagai berikut:

- Media sosial whatsapp untuk pelaporan hasil produksi anggota pada KUD.

- Komputer untuk menginput data hasil panen anggota oleh staf KUD, kemudian dicetak dengan printer untuk menginformasikan hasil penjualan TBS yang hasilnya sebagian masuk ke tabungan di rekening koperasi.

- Aplikasi mobile KUD berbasis Syariah (KS Syariah). Aplikasi ini dapat diunduh melalui HP android pada layanan Playstore. Banyaknya program yang dibuat ini masih diinisiasi oleh pengurus KUD. Aplikasi mobile KUD-Syariah ini menyediakan layanan informasi rekening tabungan (Simpanan Sukarela), informasi terkait produk dan fasilitas dari KUD Tunas Muda, serta multipayment untuk pembayaran listrik, BPJS, 
transfer ke semua bank, pembelian pulsa, dan layanan lain yang terkait.

- Tersedianya tenaga yang mengetahui pelaksanaan digitalisasi

Pelaksanaan digitalisasi di KUD Tunas Muda sudah berjalan, khususnya untuk kegiatan yang berkenaan dengan pencatatan hasil panen dan transaksi keuangan anggotanya. Dengan kondisi ini, koperasi telah dapat menciptakan ekosistem digital terkait dengan usaha kelapa sawit dengan beberapa catatan untuk dapat meningkatkan internalisasi praktik digital dalam usaha petani rakyat.

Kekuatan internal KUD Tunas Muda ialah pengurus yang kebanyakan merupakan generasi muda dengan literasi digital yang cukup memadai sehingga sangat mendukung untuk transformasi digital, bahkan ada pengurus yang dapat mengoperasikan drone. Fasilitas laptop atau komputer umum serta wifi di KUD bisa dimanfaatkan oleh staf dan pengurus KUD. Dalam struktur di koperasi, sudah ada seorang staf yang bertugas khusus mengatur berjalannya koneksi internet di dalam koperasi. Hal ini mendukung kaderisasi pengurus terutama yang 'melek' digital.

Berdasarkan faktor-faktor ini, dapat disimpulkan bahwa jaringan infrastruktur telekomunikasi sudah ada. Terdapat beberapa provider yang dapat mendukung digitalisasi, tetapi masih ada provider yang sinyalnya kurang kuat di beberapa lokasi. Selanjutnya, tenaga yang menerapkan digitalisasi di KUD Tunas Muda sudah mumpuni, terutama dengan aplikasi yang sudah digunakan, yaitu mobile koperasi. Bagaimanapun, pemanfaatan aplikasi ini masih terbatas. Oleh karena itu, agar digitalisasi perkebunan kelapa sawit berjalan, fasilitas ini masih perlu ditingkatkan, seperti untuk penyediaan input, budi daya, pemasaran hingga pembayaran. Tenaga yang sudah ada perlu diberi pendampingan agar dapat memanfaatkan fasilitas yang ada pada sistem digitalisasi yang tengah dirancang. Faktor terakhir adalah lembaga pelaksana. Berdasarkan kajian ini, lembaga pelaksana adalah KUD Tunas Muda, karena KUD ini telah berpengalaman serta telah memiliki tenaga yang dapat mendukung serta melaksanakan digitalisasi perkebunan sawit rakyat.

Selain faktor yang mendukung pengembangan digitalisasi pada KUD Tunas Muda, dalam operasionalnya sedikitnya ada tiga kendala yang ada dalam upaya digitalisasi perkebunan sawit rakyat ini, yaitu jaringan infrastruktur telekomuniksi, pemahaman tentang penggunaan fasilitas TI terutama di kalangan usia lanjut, dan masih banyak petani anggota yang menjual TBS ke tengkulak.

- Jaringan infrastruktur telekomunikasi kurang baik. Sesungguhnya jaringan infrastruktur telekomunikasi di kawasan ini telah lengkap dengan provider seperti Telkomsel, Indosat, dan XL. Oleh karena itu di koperasi ini telah tersedia fasilitas wifi, walaupun masih ada masalah dan gangguan jaringan. Berdasarkan hasil pengecekan speed-test, wifi berjalan dengan baik, tetapi ada kalanya kekuatan jaringan internet ini melemah. Gugus tugas khusus
KUD yang mengurusi penggunaan sinyal internet di dalam koperasi juga belum tersedia sehingga berdampak pada kegiatan operasional koperasi terkait dengan pemanfaatan faslitas telekomunikasi yang ada.

- Pemahaman tentang penggunaan fasilitas TI informasi pada perangkat telepon genggam terutama oleh usia lanjut. Koperasi Tunas Muda telah berumur lebih dari 20 tahun. Anggota koperasi ini adalah para transmigran. Lebih dari 50\% anggota berpendidikan sekolah dasar (SD). Berdasarkan hasil survei, terdapat $20 \%$ petani yang berusia antara 20 hingga 50 tahun, sisanya berusia lebih dari 50 tahun (Gambar 2). Hal ini merupakan salah satu tantangan dalam pengembangan digitalisasi, karena mereka kurang memahami penggunaan telepon pintar (smart phone) dan komputer. Dalam mengembangkan digitalisasi, keterbatasan pemahaman petani dalam menggunakan fasilitas digitalisasi ini perlu mendapat perhatian, agar digitalisasi dapat terlaksana dengan baik. Beberapa hal yang dipertimbangkan adalah pembinaan, sosialisasi, atau memberdayakan generasi mudanya.

- Masih banyak petani anggota yang menjual TBS ke tengkulak sehingga kelembagaan kurang optimum. Seperti telah disampaikan, KUD Tunas Muda merupakan KUD petani plasma kelapa sawit sehingga KUD ini memiliki kontrak dari berbagai PKS. Namun, dalam beberapa tahun terakhir ini, tidak sedikit anggota koperasi yang menjual TBS tidak melalui KUD, tetapi melalui pihak lain. Ini perlu mendapat perhatian agar transformasi digital dapat mendukung perkebunan sawit rakyat yang berkelanjutan. Berdasarkan hasil wawancara dengan anggota dan pengurus KUD, petani yang menjual langsung ke tengkulak adalah karena ada potongan oleh KUD. Salah satunya adalah untuk iuran dan pembayaran kewajiban kepada KUD (simpan pinjam). Hal lainnya adalah banyak agen TBS yang berkeliling di sekitar kebun petani atau anggota KUD, yang mengakibatkan anggota tidak kompak lagi karena TBS dapat dijual kepada tengkulak.

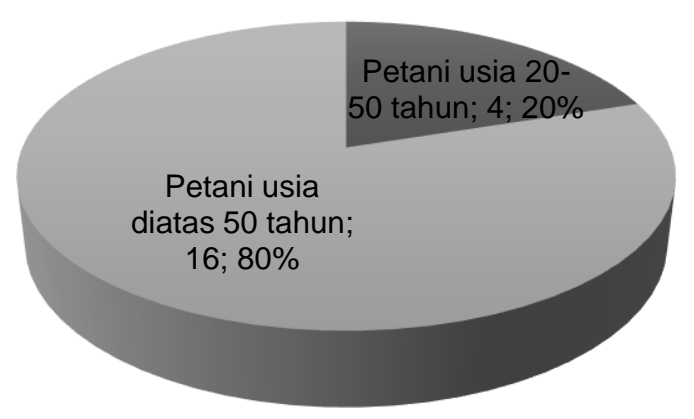

- Petani usia 20-50 tahun Petani usia diatas 50 tahun

Gambar 2 Sebaran umur petani kelapa sawit 


\section{Prioritas Strategi Kesiapan KUD Tunas Muda dalam Digitalisasi Sawit Rakyat}

Analisis prioritas stategi kesiapan KUD Tunas mengembangkan digitalisasi sawit rakyat menggunakan metode analytical hierarchy process (AHP). Dalam analisis ini diperlukan suatu kerangka (framework) guna menentukan prioritas strategi. Kerangka ini didapatkan berdasarkan atas hasil analisis sebelumnya dan beberapa literatur pendukung. Kerangka AHP dapat dilihat pada Gambar 3, yang terdiri atas tujuan, faktor yang memengaruhi kesiapan, kendala, dan prioritas strategi.

\section{Faktor}

Level faktor terdiri atas (1) tersedianya jaringan infrastruktur telekomunikasi, (2) tersedianya tenaga yang memahami pelaksanaan digitalisasi dan (3) tersedianya lembaga pelaksana. Berdasarkan hasil sintesis, faktor yang diprioritaskan untuk dapat memengaruhi kesiapan digitalisasi perkebunan kelapa sawit rakyat berdasarkan hasil olahan AHP ialah tersedianya jaringan infrastruktur telekomunikasi, dengan nilai 0,433 . Selanjutnya adalah tersedianya tenaga yang memahami pelaksanaan digitalisasi, dan faktor terakhir adalah tersedianya lembaga pelaksana (Tabel 3).

Dalam hal ini, pertama kali yang dipertimbangkan dalam digitalisasi adalah bagaimana kondisi jaringan. Hal ini sangat menentukan keberhasilan digitalisasi. Di kawasan sekitar KUD Tunas Muda sudah terdapat jaringan internet yang berasal dari berbagai provider, tetapi jaringan ini belum merata, hanya pada kawasan tertentu saja. Dengan demikian, faktor ini sangat di- prioritaskan agar gangguan jaringan dapat diminimumkan.

Faktor berikutnya adalah tenaga yang memahami digitalisasi. KUD Tunas Muda merupakan salah satu KUD yang telah memanfaatkan TI dalam kegiatan sehari-harinya walaupun ada keterbatasan jaringan pada kawasan ini. Sebagai lembaga yang telah mengaplikasikan TI, lembaga ini telah memiliki tenaga yang paham akan digitalisasi sehingga mempermudah pelaksanaan digitalisasi sawit rakyat.

\section{Kendala}

Struktur berikutnya adalah kendala dalam kesiapan digitalisasi, yaitu (1) jaringan infrastruktur telekomunikasi kurang baik, (2) pemahaman tentang penggunaan fasilitas TI pada perangkat telepon genggam terutama untuk usia lanjut, dan (3) masih banyak petani anggota yang menjual TBS ke tengkulak sehingga kelembagaan kurang optimum. Berdasarkan hasil analisis AHP, pemahaman tentang penggunaan teknologi pada para anggota agak terkendala, terutama anggota yang berusia lanjut, dengan nilai 0,519 (Tabel 4). Hal ini dapat dipahami karena koperasi ini merupakan salah satu koperasi yang sudah lama berdiri, yaitu sejak tahun 1990, sehingga tidak sedikit anggotanya yang telah berusia lanjut. Kendala ini adalah karena pengetahuan tentang TI yang kurang mutakhir.

Kendala selanjutnya adalah jaringan infrastruktur yang kurang baik di kawasan ini, yakni dengan nilai 0,286 (Tabel 4). Terakhir adalah masih banyak anggota yang menjual TBS ke tengkulak, sehingga kegiatan koperasi tidak optimum. Hal ini karena posisi tawar perkebunan rakyat kelapa sawit dalam rantai

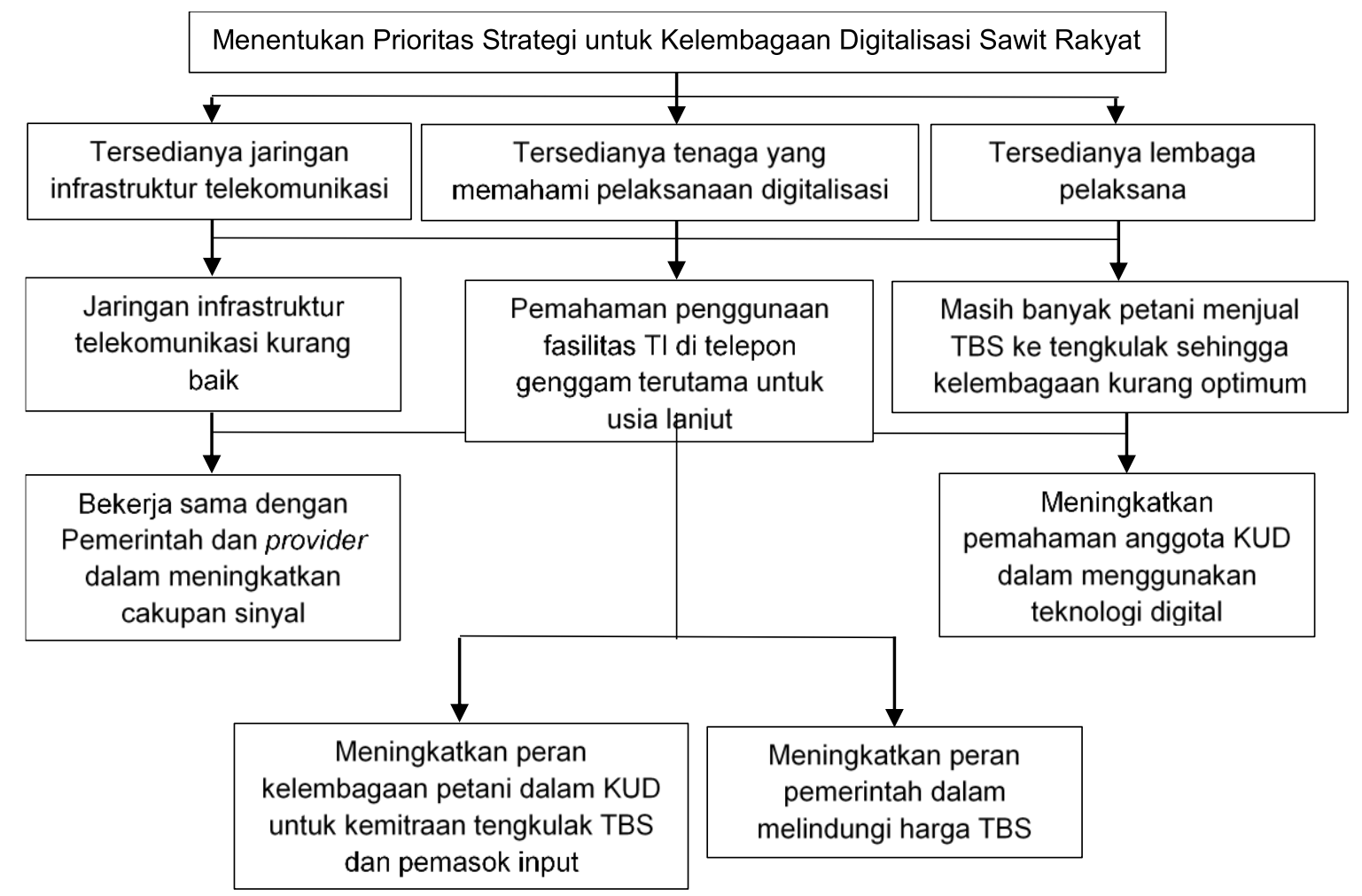

Gambar 3 Kerangka AHP strategi kesiapan digitalisasi sawit rakyat 
nilai industri kelapa sawit Indonesia relatif rendah dan hanya sebatas pemasok TBS ke PKS (Amalia et al. 2017). Oleh karena itu, pengelola KUD dapat meningkatkan hubungan yang lebih baik lagi dengan anggota untuk menumbuhkan jiwa kerja sama (Syarfi et al. 2018).

\section{Strategi}

Strategi yang dipertimbangkan untuk meningkatkan kesiapan kelembagaan digitalisasi kelapa sawit rakyat adalah (1) bekerja sama dengan Pemerintah dan provider dalam meningkatkan cakupan sinyal; (2) meningkatkan peran kelembagaan petani dalam KUD untuk kemitraan dengan tengkulak TBS dan pemasok input; (3) meningkatkan pemahaman petani sawit terutama anggota KUD dalam menggunakan teknologi dan informasi digital guna mendukung kegiatan digitalisasi perkebunan sawit, dan (4) memerlukan campur tangan pemerintah dalam melindungi petani sawit rakyat dari aspek pasar, terutama masalah harga. Rida (2011) menyatakan bahwa dengan peran yang baik yang sesuai dengan fungsi dan tugas lembaga-lembaga pendukung, yaitu kelompok tani, gabungan kelompok tani (gapoktan), koperasi, penyuluh pertanian lapang (PPL) dan Pemerintah, maka posisi tawar petani dan sekaligus pendapatan petani dapat meningkat.

Berdasarkan hasil sintesis, strategi yang diprioritaskan adalah peningkatan pemahaman petani terutama anggota KUD Tunas Muda dalam menggunakan teknologi dan informasi digital untuk mendukung kegiatan digitalisasi perkebunan sawit dengan nilai sebesar 0,393 (Tabel 5). Seperti yang telah dibahas sebelumnya, pemahaman akan pemanfaatan digitalisasi ini terkendala oleh anggota yang telah berumur lebih dari 50 tahun. Hal ini perlu dipertimbangkan untuk diatasi karena jika pemahaman petani akan digitalisasi minim, maka program pengembangan digitalisasi akan terhambat. Kondisi petani seperti ini umum dengan di Indonesia, misalnya di Deli Serdang. Penelitian Damanik (2012) menyatakan bahwa masyarakat di Kabupaten Deli Serdang, Provinsi Sumatra Utara, masih memiliki pengetahuan teknologi informasi dan komunikasi (TIK) yang relatif rendah, khususnya dalam pengetahuan dalam mengakses internet. Hal ini dapat disebabkan oleh tingkat pendidikan masyarakat yang masih relatif rendah, ataupun tingkat ekonomi masyarakat yang masih menganggap teknologi sebagai barang mahal. Dengan demikian, sebelum pelayanan publik berbasis e-government diterapkan perlu kiranya meningkatkan pengetahuan masyarakat akan TIK terlebih dahulu, dengan cara sosialisasi yang mendalam atau mengadakan pelbagai pelatihan.

Beberapa hal yang dapat diturunkan dari prioritas strategi ini adalah dengan menyediakan pendampingan dalam menggunakan alat komunikasi kepada para anggotanya yang memiliki keterbatasan dalam menggunakan telepon pintar. Hal ini dapat dilakukan dengan menyosialisasikan kepada anggota keluarga dari petani yang kesulitan dalam menggunakan telepon pintar, misalnya kepada para milenial yang ada, khususnya kepada anggota keluarganya.

\section{KESIMPULAN}

Peran pengurus koperasi cukup besar dalam menginisiasi dan membangun sistem digital dalam layanan untuk petani sawit yang menjadi anggotanya. Hal ini dikarenakan KUD Tunas Muda telah berpengalaman dalam melaksanakan digitalisasi, walaupun saat ini fungsinya ini masih terbatas. Kendala utama dalam kesiapan digitalisasi sawit rakyat adalah

Tabel 3 Prioritas faktor dalam kesiapan KUD Tunas Muda dalam melaksanakan digitalisasi kelapa sawit

\begin{tabular}{clcc}
\hline No & \multicolumn{1}{c}{ Faktor } & Nilai & Prioritas \\
\hline 1 & Tersedianya jaringan infrastruktur telekomunikasi & 0,443 & 1 \\
2 & Tersedianya tenaga yang memahami pelaksanaan digitalisasi & 0,429 & 2 \\
3 & Tersedianya lembaga pelaksana & 0,129 & 3 \\
\hline
\end{tabular}

Tabel 4 Kendala yang ada dalam kesiapan KUD Tunas Muda dalam melaksanakan digitalisasi kelapa sawit

\begin{tabular}{clcr}
\hline No & \multicolumn{1}{c}{ Faktor } & Nilai & Prioritas \\
\hline 1 & Jaringan infrastruktur telekomunikasi kurang baik & 0,286 & 2 \\
2 & Pemahaman tentang penggunaan fasilitas TI di telepon genggam untuk usia lanjut & 0,519 & 1 \\
3 & $\begin{array}{l}\text { Masih banyak petani anggota yang menjual TBS ke tengkulak sehingga kelembagaan } \\
\text { kurang optimum }\end{array}$ & 0,194 & 3 \\
\hline
\end{tabular}

Tabel 5 Prioritas strategi dalam kesiapan KUD Tunas Muda dalam melaksanakan digitalisasi kelapa sawit

\begin{tabular}{clcc}
\hline No & \multicolumn{1}{c}{ Faktor } & Nilai & Prioritas \\
\hline 1 & Bekerja sama dengan Pemerintah dan provider dalam meningkatkan cakupan sinyal & 0,269 & 2 \\
2 & $\begin{array}{l}\text { Meningkatkan peran kelembagaan petani dalam KUD Tunas Muda untuk kemitraan } \\
\text { tengkulak TBS dan pemasok input }\end{array}$ & 0,207 & 3 \\
3 & $\begin{array}{l}\text { Meningkatkan pemahaman petani sawit terutama anggota KUD Tunas Muda dalam } \\
\text { menggunakan teknologi dan informasi digital guna mendukung kegiatan digitalisasi }\end{array}$ & 0,393 & 1 \\
& $\begin{array}{l}\text { perkebunan sawit } \\
\text { Memerlukan campur tangan pemerintah dalam melindungi petani sawit rakyat dari } \\
\text { aspek pasar, terutama masalah harga }\end{array}$ & 0,132 \\
\hline
\end{tabular}


penggunaan teknologi pada anggota yang rata-rata telah berusia lanjut sehingga mereka perlu diberi pemahaman tentang cara menggunakan teknologi digitalisasi atau dengan memberi pengajaran kepada anggota keluarga yang paham tentang TI sehingga tidak menjadi batu sandungan dalam penggunaan digitalisasi yang berkelanjutan. Kendala lain adalah adanya anggota yang tidak menjual TBS nya melalui koperasi.

Faktor yang paling diprioritaskan dalam kelembagaan koperasi digitalisasi kelapa sawit adalah tersedianya jaringan infrastruktur telekomunikasi, sedangkan kendala yang paling ditekankan adalah perlunya pemahaman tentang penggunaan fasilitas $\mathrm{TI}$ di telepon genggam untuk usia lanjut. Oleh karena itu, strategi yang paling diprioritaskan adalah peningkatan pemahaman petani sawit terutama anggota KUD Tunas Muda dalam menggunakan teknologi dan informasi digital guna mendukung kegiatan digitalisasi perkebunan sawit.

\section{UCAPAN TERIMA KASIH}

Penulis mengucapkan terima kasih dan penghargaan yang sebesar-besarnya kepada Kementerian Pendidikan dan Kebudayaan yang telah mendanai kegiatan ini dengan skema Penelitian Terapan Unggulan Perguruan Tinggi (PTUPT) berdasarkan SPK No 2764/IT3.L1/PN/2020.

\section{DAFTAR PUSTAKA}

Afifah HP, Nurliza \& Kurniati D. 2021. Cooperatives as the strengthening effort for oil palm replanting program in Landak Regency SOCA. Jurnal Sosial Ekonomi Pertanian. 15(1): 29-41.

Amalia R, Nurkhoiry R, Nasution ZPS, Kurniawan A. 2017. Analisis kesiapan petani dan koperasi dalam program peremajaan perkebunan rakyat kelapa sawit (studi kasus petani lingkup Ophir, Kab. Pasaman Barat, Provinsi Sumatra Barat). Jurnal Penelitian Kelapa Sawit. 25(3): 171-182.

Ciruela-Lorenzo AM, Del-Aguila-Obra AR, PadillaMeléndez A, Plaza-Angulo JJ. 2020. Digitalization of agri-cooperatives in the smart agriculture context. proposal of a digital diagnosis tool. Sustainability. 12(1325): 1-15. https://doi.org/10.3390/su12041 325

Damanik MP. 2012. Literasi internet masyarakat dalam implementasi pelayanan publik berbasis $e$ government di Kabupaten Deli Serdang Provinsi Sumatra Utara. Widyariset. 15(1).

Falatehan AF. 2016. Analytical Hierarchy Process (AHP) Teknik Pengambilan Keputusan untuk
Pembangunan Daerah. Yogyakarta (ID): Indomedia Pustaka.

Falatehan AF, Setiawan BI. 2020. Economic Risk Characteristics of Value Chain and Identifying Sources of Uncertainty in Policy Making: Case of Indonesia Palm Oil. Supply Chain Resilience Reducing Vulnerability to Economic Shocks, Financial Crises, and Natural Disasters. Singapore (SG): Springer. https://doi.org/10.1007/978-9811-5 2870-5_5

Mosher AT. 1991. Getting Agriculture Moving. New York (US): Frederick A. Praeger, Inc. Publishers.

Rida, WN. 2011. Analisis bentuk kerja sama petani dengan lembaga-lembaga pendukung pengembangan agribisnis kakao di Kenagarian Sekucur, Kecamatan V Koto Kampung Dalam, Kabupaten Padang Pariaman [Skripsi]. Padang (ID): Universitas Andalas.

Putra CP, Sadono D, Susanto D. 2020. Persepsi petani tentang koperasi perkebunan kelapa sawit rakyat di Kecamatan Kongbeng Kabupaten Kutai Timur. Jurnal Penyuluhan. 16(1): 134-146. https://doi.org $/ 10.25015 / 16202028295$

Saaty TL. 1994. Fundamentals of decision making and priority theory with the analytic hierarchy process. Pittsburgh (US): RWS Publications.

Sari DAP, Falatehan AF, Ramadhonah RY. 2019. The social and economic impacts of peat land palm oil plantation in Indonesia. In: 1st Workshop on Engineering, Education, Applied Sciences, and Technology. Journal of Physics Conference Series. (2018). IOP Publishing. 1364. https://doi.org/10.10 88/1742-6596/1364/1/012017

Sani BF, Harianto, Falatehan AF. 2017. Strategi kesiapan pemerintah kota bogor dalam penerapan perencanaan pembangunan berbasis e-planning. Jurnal Manajemen Pembangunan Daerah. 9(1). https://doi.org/10.29244/jurnal_mpd.v9i1.27545

Savic D. 2019. From Digitization, through Digitalization, to Digital Transformation. [Internet]. [diunduh Jan]. Tersedia pada http://www.infotoday.com/ OnlineSearcher/Articles/Features/From-Digitization -Through-Digitalization-to-Digital-Transformation -1 29664.shtml

Sujarwo, Listiawati R. 2018. Pengembangan bisnis koperasi kampus (era milenial dan revolusi industri ke-4.0). Jurnal Mitra Akademia. 1(2). https://doi.org/10. 32722/mapnj.v1i2.1354

Syarfi IW, Noer M, Utami AM. 2019. Empowerment of the Smallholders' Cooperative for Palm Oil Plantation Replanting of Pir-Trans Scheme in Dharmasraya District West Sumatera Province. In: 1st International Conference on Innovation in Research (ICIIR). 2018. Advances in Economics, 
Business and Management Research. 88: Zulhaedar F, Mardiana. 2016. Kearifan Lokal Budidaya 127-132. https://doi.org/10.2991/iciir-18.2019.23 Padi Gogo di Lahan Sub Optimal Kabupaten

Windasari NPE, Budhi MKS. 2013. Analisis pengaruh tumpangsari terhadap pendapatan petani di Desa Munduktemu Kabupaten Tabanan. E-Jurnal Ekonomi Pembangunan Universitas Udayana. 2(5): Lombok Utara. Seminar Nasional Agroinovasi Spesifik Lokasi untuk Memantapkan Ketahanan Pangan pada Era Masyarakat Ekonomi ASEAN. 254-259. 